\title{
Civic Education in Europe: Pedagogic Challenge versus Social Reality
}

\author{
Elena Arbués \\ Department of Education, University of Navarra, Pamplona, Spain \\ Email: earbues@unav.es
}

Received 2 April 2014; revised 18 May 2014; accepted 4 June 2014

Copyright (C 2014 by author and Scientific Research Publishing Inc. This work is licensed under the Creative Commons Attribution International License (CC BY). http://creativecommons.org/licenses/by/4.0/

(c) (i) Open Access

\begin{abstract}
Since the final decade of the 20th century western democracies have witnessed the ongoing development and consolidation of education for democratic citizenship. It has been seen as a solution to specific problems faced by our societies (Cortina, 1997; Altarejos \& Naval, 2005; Bolivar, 2007). Governments have attempted to implement the various recommendations of the Council of Europe $(2002,2010)$. The introduction of educational reforms and the ongoing development of curricula have provided an opportunity to include civic education in the national curriculum of most European countries (Naval, Print, \& Veldhuis, 2002). The aim of this article is to suggest the likely future tendencies for this situation within Europe, bearing in mind, among other things, the challenges posed by an increasingly globalised and technological society as well as the objectives of the European Higher Education Area.
\end{abstract}

\section{Keywords}

Civic Education, Social Skills and Citizenship, Social Participation, Mediated Citizenship, European Area for Higher Education

\section{Introduction}

For many years, education has concerned itself with preparing people to coexist with their peers and assume the responsibilities that exist in society entails. Today, more than ever before, educational policy highlights and prioritises the social aspects of education. Since the final decade of the 20th century western democracies have witnessed the ongoing development and consolidation of education for citizenship (Callan, 1997; Westheimer \& Kahne, 2002; Putnam, Feldstein, \& Cohen, 2003; Torney-Purta \& Amadeo, 2003; Naval, 2003; Torney-Purta, 2004; Kerr, 2004; Saha, Print, \& Edwards, 2007). An education for democratic citizenship, without incorporating every possible dimension, is part of social education. 
This expansion in civic education is viewed as being a social necessity, as a response to the problems of a society that is excessively technical (Naval, Iriarte, \& Laspalas, 2001). It is seen as the solution to many problems posed by our contemporary societies. A way to deal with questions arising, for example, from globalisation, multiculturalism, migration, the use of information and communication technologies, violence, the lack of civic commitment, the breaking of social and family ties, the lack of respect for society, the need to strengthen the social conscience and encourage social participation, among others (Sartory, 2001; Altarejos \& Naval, 2005; Bolívar, 2007; Pérez Juste, 2007; Pérez Serrano, 2008). Education which is concerned with the civic dimension is perceived as helping to overcome the individualism that isolates individuals from the community in which they live (Cortina, 1997; Camps \& Giner, 1998; Bartolomé, 2002). Governments try to implement the guidance given by the Council of Europe by undertaking educational reforms which aim to educate young people in democratic citizenship (Naval, Print, \& Veldhuis, 2002). However, there is no consensus on how this should be achieved or where it should feature in the curriculum. The Recommendations of the Committee of Ministers of the Council of Europe to Member States (2002) highlight the key role played by the family in education for democratic citizenship as well as the importance of the media and new information technologies. Despite the underlying truth contained in these statements it still appears, from the detailed objectives and subject matter they embody, that the duty and responsibility for delivering it actually rest with schools. The task they have been charged with is disproportionate. It could be argued that they represent aspirational objectives which are not wholly achieveable but which, nevertheless, reflect the current pedagogic reality (Altarejos, 2006).

In 2012, a new Recommendation of the Council of Europe (2012) suggested some additional parameters. Among them is that Member States are encouraged to include democratic citizenship programmes in all forms of education and training whether formal, or informal, including at higher education level, particularly within teacher education courses. One of the main reasons for this is to reinforce the ability of students to participate within society. Member states are also encouraged to develop the necessary criteria for evaluating these programmes as well as to initiate and develop research into innovative practice, teaching methodology and assessment strategies.

The following section will deal with how this issue is currently being dealt with and what future trends in this area are likely to be.

\section{Education for Democratic Citizenship in European Countries}

Within Europe two distinct reference points can be identified which enable a clearer understanding of this movement in favor of education for democratic citizenship. The first is the fall of the Berlin Wall, together with all of the surrounding circumstances and subsequent consequences it had, principally for countries in eastern and central Europe. The door to a new era in the history of the western world opened in 1989 with the arrival of a third wave of democracy, as some authors have called it. It meant that several countries without any previous democratic tradition had to learn to live as a democracy; and education was seen as the way to achieve this (González Torres \& Naval, 2000).

The second event, closely related to the first, was a movement which brought important consequences for society: the criticism of extreme liberalism. At the end of the 1980s various intellectual movements emerged, initially in the United States and Canada but later extending to Europe, which criticized extreme liberalism, among them, but in a very specific way, communitarianism. This is the name given by some authors to the current of criticism of liberalism when stressing the value of community (Sisón \& Naval, 2000). These tendencies share a common foundation: they highlight the personal dimension of human beings, the recovery of freedoms, but they emphasise at the same time their social dimension. This current of thought has subsequently influenced educational policy and, in particular, the promotion of an education which recognizes both the moral and civic aspects of individuals and not just their intellectual dimension.

A combination of these and other factors has meant that across Europe citizenship and education focused on citizenship have become important and compulsory elements in ensuring a high quality education. The introduction of educational reforms and subsequent curricular developments has provided an opportunity for civic education to be embedded in the national curriculum of most European countries (Naval, Print, \& Veldhuis, 2002). Examples of this include;

- The introduction of civic, legal and social education in France in 1999 with the objectives of learning how to live in society and developing a spirit of initiative. The programmes developed to this end help pupils learn to cooperate, respect the rules of the group and engage in dialogue. Furthermore the pupils are encouraged to fully participate in the life of the school (Tournier, 2006). 
- The introduction of "education for citizenship" classes in schools in England in 2002 (DfEE/QCA, 1998). From that date onwards all pupils between 11 and 16 years of age in state funded schools have had civic education classes, although each school determines how the programme is implemented and best adapted to the specific needs of its community. In general schools offer pupils the opportunity to participate actively both within and outside of the school community through school councils, consultation processes, volunteering programmes, charitable and fund raising activities, debating clubs, etc. (Keating, 2010).

- The programme "learning to live in a democracy" was established in Germany, promoted by the Federal Ministry for Education and Science and by several federal states, with the aim of enabling young people to actively participate in civic society by promoting both democratic and citizenship skills. In German it is stated explicitly that pupils have as many rights as responsibilities and in some federal states teachers actually assess the social behaviour of their pupils (Edelstein, 2004).

- In Italy new legislation provides for the inclusion of objectives and the development of skills in "education for living in society" at all stages of compulsory education. Its aim is to develop in pupils the values that support democratic citizenship (CEPC, 2007).

- The introduction of "education for citizenship and human rights" as a subject in Spain placed the promotion of democratic citizenship at the heart of educational objectives and activities (Ley Orgánica 2/2006 de Educación, 2006). Current legislation requires schools to implement transversal strategies to prepare pupils for active citizenship and to acquire social skills (Ley Orgánica 8/2013 para la mejora de la calidad educativa, 2013).

All of the above initiatives resulted from the recommendations and guidance of the Council of Europe, which will be discussed in the following section.

\section{The Recommendations of the Council of Europe}

At the Second Summit of Heads of State of the Council of Europe in 1997 the decison was taken to launch an initiative in favor of Education for Democratic Citizenship (EDC) ${ }^{1}$ with the intention of encouraging citizens to become more aware of their rights and responsibilities and increase the participation of young people in society. Since then the Council of Europe has declared its intention to promote good citizenship and to develop awareness of a European identity and has further developed the EDC Projec ${ }^{2}$. The Project offers a forum for debate among experts and professionals across Europe with the intention of defining concepts and developing strategies and good practice for EDC. As a consequence, a programme of action to promote active European citizenship was endorsed on 26 January 2004. Its aims were to promote the values and objectives of the European Union, encourage citizens to engage with them and reflect and participate in the debate about their future, thereby strengthening the relationship between citizens of different countries and inspiring new initiatives in the area of active citizenship ${ }^{3} .2005$ was declared the European Year of Citizenship through Education. On 6 April 2005 the European Commission presented to the Parliament and the Council of Europe a proposal for a new programme entitled, "Citizens for Europe" which ran until $2013^{4}$. Its key objectives were to contribute towards the construction of Europe, to create a European identity and improve mutual understanding between the citizens of Europe.

From the work being undertaken by the European Union it is evident it intends to ensure that through the education systems of member states their schools encourage the aquisition of democratic values and participation with the aim of preparing their citizens for active citizenship. The Council of Europe has issued several recommendations urging member states to implement the approved policies.

To this end Recommendation 12 (2002) relating to EDC was issued in 2002 to reaffirm the importance of education in resolving social problems ${ }^{5}$. EDC is seen as a factor for social cohesion which contributes to the defense and development of democratic societies and cultures; as such it should be at the core of both the reform

\footnotetext{
${ }^{1}$ Henceforward EDC will refer to Education for Democratic Citizenship.

${ }^{2}$ International Contact Group on Citizenship and Human Rights Education. http://www.coe.int/t/dg4/education/edc/what/icc_EN.asp ${ }^{3}$ Council Decision of 26 January 2004 Establishing a Community Action Programme to Promote Active European Citizenship (civic participation) (2004/100/EC). http://eur-lex.europa.eu/

smartapi/cgi/sga_doc?smartapi!celexplus!prod!DocNumber\&lg=es\&type_doc=Decision\&an_doc=2004\&nu_doc=100

${ }^{4}$ European Commission (2005). Proposal for a Decision of the European Parliament and Council of Europe Which Approved the "Citizens for Europe” Programme between 2007-2013 to Promote Active European Citizenship. http://eacea.ec.europa.eu/citizenship/index_en.php ${ }^{5}$ Council of Europe (2002). Recommendation of the Committee of Ministers to the Member States on Education for Democratic Citizenship Adopted by the Committee of Ministers on 16 October 2002. http://www.coe.int
} 
of and the implementation of education policies. The Recommendation proposes that the Governments of member states should make EDC a prime objective of their education policies and that through education reform they should consider introducing it at all levels of education and in all formal and informal education.

The European Comission has produced several reports via Eurydice, the European network for information on education, which analyse how EDC is delivered through schools ${ }^{6}$. The first such report, "Citizenship Education at School in Europe”, analysed how each country's education system promoted responsible citizenship through its schools. It focused on how education for citizenship was delivered in both primary and secondary schools in thirty European countries during 2004-2005. The results indicated that responsible citizenship was included in the curriculum in all of those countries, although they had different ways of delivering it: as a separate subject, integrated within other subjects or as an overarching theme. It revealed that the objectives established were focused on developing in students a political culture as well as the attitudes and values required to become responsible citizens and on nurturing active participation. However, the report also challenged member states to improve the training of teachers who deliver citizenship, to create resources and assessment centres and to do more to motivate students to participate actively in society (Eurydice, 2005).

It can be seen that, although all countries acknowledge the positive effects that citizenship education can have on young people by moulding them into active and responsable citizens, it appears the precise focus they give it differs widely between countries. The report highlighted the need to undertake further research to fully understand the various teaching methods used, the results they delivered and how they should be assessed. These remain the key challenges for the immediate future.

In 2010 the Council of Europe published a Letter on EDC and Human Rights ${ }^{7}$. It emphasised the relationship between them and how they are closely linked and mutually reinforce each other. Education in these issues is a process which continues throughout a person's life and all agencies involved in education, whether official or unofficial, play a vital role in this. One of the fundamental objectives is to strengthen the capacity of students to act at the very heart of society. Member states must incude this education at all levels; infants, primary, secondary and vocational education; and must encourage its inclusion within all Higher Education institutions. Both the initial and ongoing training of teaching staff is vital for this and must therefore be properly planned and supported with appropriate resources (Council of Europe, 2010a).

Following the publication of the Letter, the Council of Europe adopted Recommendation CM/Rec (2010)7 of the Committee of Ministers of the Member States concerning the Letter of the Council of Europe on EDC and human rights education ${ }^{8}$. This recommended putting into effect all of the measures approved in the document.

The Eurydice Network's second report "Citizenship education in Europe" published in 2012 focused on the academic year 2010-2011. It reviewed the policies and strategies countries had implemented to reform citizenship education. It also analysed the measures taken to encourage "learning through action", which is a fundamental element within an area of learning for which practical skills are essential (Eurydice, 2012).

The 2005 report identified that one of the key challenges in this area was improving the knowledge and skills of staff who taught the subject. The more recent report suggested that the upskilling of teachers of this subject must remain a significant focus for those responsible for education policy. Although several countries have revised their education study plans for citizenship in recent years, significant changes to initial and ongoing teacher training programmes remain rare. Not only teachers but Heads of schools also have important roles to play in establishing the right environment within which citizenship education can be carried out successfully. Heads can, for example, be the main drivers for creating an appropriate school culture, by encouraging all members of their community to participate actively and providing them with opportunities to undertake citizenship related activities. Very few countries in Europe yet fully recognise the crucial role of Heads of schools in relation to citizenship education (Eurydice, 2012).

\section{Current Pedagogic Challenges}

On the whole, European countries all agree on the need to include citizenship education within the school curriculum. However, the way this is defined and organised varies significantly between countries and there appears to be no general focus which prevails over others or which is adopted by a majority of countries. But, however it

\footnotetext{
${ }^{6} \mathrm{Cfr}$. http://eacea.ec.europa.eu/education/eurydice/index_en.php

${ }^{7}$ Council of Europe (2010a). Letter from the Council of Europe on Education for Democratic Citizenship and Human Rights. http://www.coe.int/t/dg4/education/edc/Charter/Charter_EN.asp

${ }^{8}$ Council of Europe (2010b). Recommendation CM/Rec (2010)7 of the Committee of Ministers to Member States on the Council of Europe Charter on Education for Democratic Citizenship and Human Rights Education. https://wcd.coe.int/ViewDoc.jsp?id=1621697
} 
is taught, it is clear that citizenship education is not just about passing on to students theoretical knowledge to improve their political awareness in areas like democracy, human rights and the workings of political institutions. All European countries agree that citizenship education should develop positive attitudes and civic values in their students.

As a consequence it can be said that:

i. The key pedagogic challenge currently facing educators in Europe is how to fully implement the required strategies. According to the definition contained in the European framework for key skill ${ }^{9}$ the civic skills needed to carry out active citizenship require knowledge of various basic democratic concepts, such as; understanding what a society is and what social and political movements are; the process of European integration and the structures of the EU; key social developments of the past and present. Civic skills demand other skills such as critical thinking and communication skills as well as the ability and desire to participate actively in the public arena. Other components of civic skills comprise the sense of belonging to a society at different levels, respect for democratic values, for diversity and support for sustainable development. Furthermore, it will be necessary to place ever greater emphasis on promoting the participation of students at all levels of education, whether within their schools, universities or in the wider society.

ii. The next challenge will be to promote mediated education through the social aspect of using technology, since it is clear that communication technology can encourage young people to participate in society (Gonzálvez, 2011) or, at the very least, it provides them with the opportunity to do so. The fact that we live in globalised and mediated societies enables us to recognise how information and communication technologies can help in this regard. The concept of mediated citizenship, which has been prevalent for several years in the world of communication, is now becoming a significant force in the world of education. Technology and access to information are two important realities in a democratic society which can help to reinforce mediated citizenship.

iii. Finally, there is a body of opinion that believes it is vital to maintain the social dimension of higher education. It seems logical that the efforts to educate students in primary and secondary education about their civic responsibilities should be continued into higher education. In the 1999, Bologna Declaration the European Ministers for Education (1999) accepted the challenge of creating a European higher education area to achieve more compatibility and greater competition between higher education systems. This required a range of objectives to be achieved within the first decade of the current century; all of them engaged with the wider perspective of consolidating and enriching European citizens and providing them with the skills required for the development and reinforcement of their intellectual, cultural, social, scientific and technological dimensions (Para.1). There already exists within higher education across Europe a trend towards encouraging social participation due to, among other things, the impact it has on the development of citizens (Egerton, 2002). It follows therefore that proposals for civic education in universities should take full account of the prior knowledge and experience of students within the education system.

\section{Conclusion}

Teaching the knowledge, skills and attitudes that allow young people to become active citizens capable of shaping our democratic societies in Europe is one of the key challenges facing education systems in the 21st Century. Citizenship education is one of the main approaches employed in European countries to help young people gain the social and citizenship skills they will need in their future lives.

Without falling into the deception that civic education is a panacea it is nevertheless possible to acknowledge the significant influence that schools can have as appropriate places in which to foster a more just society and a greater moral, civic and political approach among the majority of its citizens. It seems obvious to say that to learn all these implies more than just the gaining of some knowledge. It actually entails nurturing good citizens with both well founded personal and social values plus sufficient initiative to become fully involved with their social environment. This falls outside the scope of any single subject area or module and so needs to be seen within the context of an integrated education which embraces all of the intellectual, social, affective, aesthetic and moral aspects of human beings (Naval \& Arbués, 2008). At the same time it requires the collaboration of schools but of other parties as well, principally families, but also the media and associations that serve culture

${ }^{9}$ European Commission (2007). Key Competencies for Lifelong Learning. A European Reference Framework. Luxembourg: Office for Official Publications of the European Communities. http://ec.europa.eu/dgs/education_culture/publ/pdf/ll-learning/keycomp_es.pdf 
and young people, etc.

It appears that the training of teachers capable of delivering citizenship education and developing appropriate support materials produce other key challenges. Up to now citizenship education has been delivered in most countries by generalist teachers or by specialists in social sciences, history, philosophy or ethics. In some European countries citizenship is just one element within the general ongoing training of teachers whilst in others it features as an important part of both initial and ongoing teacher education. When it comes to the professional development of teachers both initial and ongoing education are essential. Education can often be overloaded with activities that are not of primary importance or, indeed, entirely relevant but which are connected to other social issues, such as the consumption of drugs or alcohol, sex education, ecological concerns, education to promote peace, road safety, developing healthy habits, a balanced diet, participating in sport, consumer education, etc. These themes can create excessive work for schools. Education can obviously contribute to the solution but then so can hospitals, political parties, the media, businesses, etc. They are not, strictly speaking, the sole and direct responsibility of schools. On the other hand, schools do have responsibility for the initial and ongoing education of teachers, the quality of their education, the leadership and governance of the education system and schools, etc. Educational reform or the introduction of new subjects cannot happen without teachers playing a central role. They must be encouraged to teach civic education but moreover to become actively involved in it so that they can teach their students about the kinds of social interactions that they themselves are involved in.

The current EU Strategy for Youth (2010-2018) includes the key objective of encouraging active citizenship, social inclusion and solidarity among all young people. The strategy proposes various courses of action aimed at the development of citizenship through both formal and informal educational activities, such as participating in civil society and representative democracy and harnessing the voluntary sector as a vehicle for social inclusion and citizenship (Council of Europe, 2010c). Together this represents another proposal for action that could contribute to achieving the objectives associated with citizenship.

\section{References}

Altarejos, F. (2006). Ciudadanía democrática e identidad europea: Un escollo para la educación. In C. Naval, \& M. Herrero (Eds.), Educación y ciudadanía en una sociedad democrática (pp. 61-77). Madrid: Encuentro.

Altarejos, F., \& Naval, C. (2005). La educación cívica en una sociedad globalizada. Revista Galega do Ensino, 46, 841-862.

Bartolomé, M. (2002). Educar para una ciudadanía intercultural. In M. Bartolomé (Coord.), Identidad y ciudadanía. Un reto a la educación intercultural (pp. 131-161). Madrid: Narcea.

Bolívar, A. (2007). Educación para la ciudadanía. Algo más que una asignatura. Barcelona: Graó.

Callan, E. (1997). Creating Citizens, Political Education and Liberal Democracy. Oxford: Clarendon Press.

Camps, V., \& Giner, S. (1998). Manual de civismo. Barcelona: Ariel.

CEPC (2007). La educación para la ciudadanía en: Alemania, España, Francia, Italia y Reino Unido. Boletín de Documentación, No. 30, 56-162.

Cortina, A. (1997). Ciudadanos del mundo. Madrid: Alianza Editorial.

Council of Europe (2002). Recomendación del Comité de Ministros a los Estados miembros sobre la educación para la ciudadanía democrática adoptada por el Comité de Ministros el 16 de octubre de 2002. http://www.coe.int

Council of Europe (2010a). Letter from the Council of Europe on Education for Democratic Citizenship and Human Rights. http://www.coe.int/t/dg4/education/edc/Charter/Charter_EN.asp

Council of Europe (2010b). Recommendation CM/Rec (2010)7 of the Committee of Ministers to Member States on the Council of Europe Charter on Education for Democratic Citizenship and Human Rights Education.

https://wcd.coe.int/ViewDoc.jsp?id=1621697

Council of Europe (2010c). Resolución del Parlamento Europeo, de 18 de mayo de 2010, sobre una estrategia de la UE para la juventud: Inversión y capacitación (2009/2159(INI)).

http://www.europarl.europa.eu/sides/getDoc.do?pubRef=-//EP//TEXT+TA+P7-TA-2010-0166+0+DOC+XML+V0//EN

Council of Europe (2012). La educación para la ciudadanía en Europa. Bruselas: Agencia Ejecutiva en el ámbito Educativo, Audiovisual y Cultural. http://eacea.ec.europa.eu/education/eurydice/index en.php

Declaración de Bolonia de 19 de junio de 1999. http://www.educacion.gob.es/boloniaeees/que.html

DfEE/QCA (1998). Education for Citizenship and the Teaching of Democracy in Schools. London: DfEE/QCA. 
Edelstein, W. (2004). The Struggle for Citizenship Education in German Schools. The UK-German Education Policy Seminar on Cultural Diversity in School Education, Berlin, 29-30 November 2004.

Egerton, M. (2002). Higher Education and Civic Engagement. The British Journal of Sociology, 53, 603-620. http://dx.doi.org/10.1080/0007131022000021506

Eurydice (2005). Citizenship Education at School in Europe. Brussels: Eurydice. http://eacea.ec.europa.eu/education/eurydice/index_en.php

Eurydice (2012). Citizen Education in Europe. Brussels: Education, Audiovisual and Culture Executive Agency. http://eacea.ec.europa.eu/education/eurydice/documents/thematic_reports/139EN.pdf

González Torres, M. C., \& Naval, C. (2000). Una aproximación a la educación para la ciudadanía en Europa en la última década. In C. Naval, \& J. Laspalas (Eds.), La educación cívica hoy (pp. 221-248). Pamplona: Eunsa.

Gonzálvez, V. (2011). Education for Democratic Citizenship in a Digital Culture. Comunicar, 36, 131-138. http://dx.doi.org/10.3916/C36-2011-03-04

Keating, A. (2010). Embedding Citizenship Education in England: The Policies, Practices, and Challenges of Encouraging Citizenship Learning in Schools. In C. Naval, S. Lara, C. Ugarte, \& C. Sádaba (Eds.), Educar para la comunicación y la cooperación social (pp. 15-32). Pamplona: CoAn.

Kerr, D. (2004). Changing the Political Culture: Reviewing the Progress of the Citizenship Education Initiative in England. The American Educational Research Association Conference, San Diego, 12-16 April.

Ley Orgánica 2/2006, de 3 de mayo, de Educación (BOE No. 106, de 4 de mayo de 2006).

Ley Orgánica 8/2013, de 9 de diciembre, para la mejora de la calidad educativa (BOE No. 295, de 10 de diciembre de 2013).

Naval, C. (2003). Orígenes recientes y temas clave de la educación para la ciudadanía democrática actual. Revista de educación, núm. extraordinario, 169-189.

Naval, C., \& Arbués, E. (2008). Ciudadanos de manual? Nuestro tiempo, 645, 25-35.

Naval, C., Iriarte, C., \& Laspalas, J. (2001). En torno a la educación moral y cívica. San José de Costa Rica: Promesa.

Naval, C., Print, M., \& Veldhuis, R. (2002). Education for Democratic Citizenship in the New Europe: Context and Reform. European Journal of Education, 37, 107-128. http://dx.doi.org/10.1111/1467-3435.00097

Pérez Juste, R. (2007). Educación, ciudadanía y convivencia. Diversidad y sentido social de la educación. Revista de Pedagogía Bordón, 59, 239-260.

Pérez Serrano, G. (2008). La educación como respuesta a los retos que plantea la escuela. Revista de Pedagogía Bordón, 60, 15-29.

Putnam, R., Feldstein, L., \& Cohen. D. (2003). Better Together. New York: Simon and Schuster.

Saha, L. J., Print, M., \& Edwards, K. (Eds.) (2007). Youth and Political Participation. Rotterdam: Sense Publishers.

Sartory, G. (2001). La sociedad multiétnica: Pluralismo, multiculturalismo y extranjeros. Madrid: Taurus.

Sisón, A. J., \& Naval, C. (2000). La propuesta comunitarista en América y Europa. Arbor: Ciencia, pensamiento y cultura, 652, 589-612.

Torney-Purta, J. (2004). An Overview of Secondary Analysis of the IEA Civic Education Study, Its Impact and Directions for the Future. IEA Civic Papers. http://www.iea.nl/irc2004-cived.html

Torney-Purta, J., \& Amadeo, J.-A. (2003). A Cross-National Analysis of Political and Civic Involvement among Adolescents. PSOnline. http://www.apsanet.org/imgtest/CrossAnalysisPoliticalCivicAdolescents.pdf

Tournier, V. (2006). Response: France 1, IDEA A Questionnaire on Civic Education. International Institute for Democracy and Electoral Assistance. http://www.civiced.idea.int/public/viewSurveyResponse.jsp?srId=4729460

Westheimer, J., \& Kahne, M. (2002). What Kind of Citizen? The Politics of Educating for Democracy. Encounters on Education, 4, 47-64. 
Scientific Research Publishing (SCIRP) is one of the largest Open Access journal publishers. It is currently publishing more than 200 open access, online, peer-reviewed journals covering a wide range of academic disciplines. SCIRP serves the worldwide academic communities and contributes to the progress and application of science with its publication.

Other selected journals from SCIRP are listed as below. Submit your manuscript to us via either submit@scirp.org or Online Submission Portal.
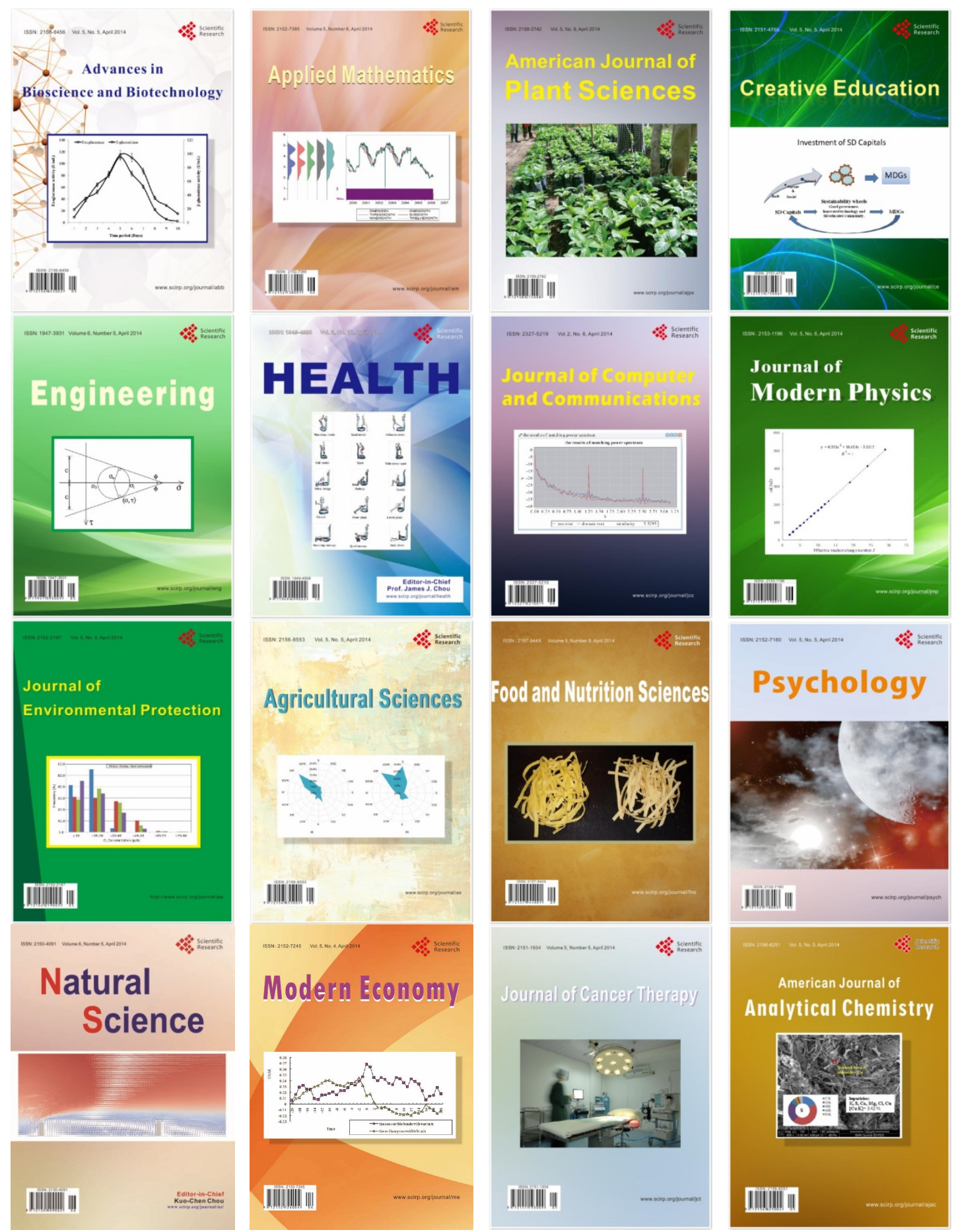